\title{
Reading Strategies for Coping with Information Overload, ca.1550-1700
}

\section{Citation}

Blair, Ann. 2003. Reading strategies for coping with information overload, ca.1550-1700. Journal of the History of Ideas 64, no. 1: 11-28.

\section{Published Version}

http://dx.doi.org/10.2307/3654293

\section{Permanent link}

http://nrs.harvard.edu/urn-3:HUL.InstRepos:3228379

\section{Terms of Use}

This article was downloaded from Harvard University's DASH repository, and is made available under the terms and conditions applicable to Other Posted Material, as set forth at http:// nrs.harvard.edu/urn-3:HUL.InstRepos:dash.current.terms-of-use\#LAA

\section{Share Your Story}

The Harvard community has made this article openly available.

Please share how this access benefits you. Submit a story.

\section{Accessibility}




\section{Reading Strategies for Coping With Information Overload ca. $1550-1700$}

Ann Blair

The "multitude of books" was a subject of wonder and anxiety for authors who reflected on the scholarly condition in the sixteenth through the eighteenth centuries. In the preface to his massive project of cataloguing all known books in the Bibliotheca univeralis (1545) Conrad Gesner complained of that "confusing and harmful abundance of books," a problem which he called on kings and princes and the learned to solve. ${ }^{1}$ By 1685 the situation seemed absolutely dire to Adrien Baillet, who warned:

We have reason to fear that the multitude of books which grows every day in a prodigious fashion will make the following centuries fall into a state as barbarous as that of the centuries that followed the fall of the Roman Empire. Unless we try to prevent this danger by separating those books which we must throw out or leave in oblivion from those which one should save and within the latter between what is useful and what is not. ${ }^{2}$

In this way Baillet claimed to have warded off barbarity itself with his collection of judgments on the learned in his nine-volume (and still only half-completed) Jugemens des sçavans.

I am grateful for helpful comments from Mordechai Feingold, Anthony Grafton, Brian Ogilvie, William Sherman, Nancy Siraisi, and Helmut Zedelmaier.

${ }^{1}$ Conrad Gesner, Bibliotheca universalis (Zurich, 1545), sig. *3v .

${ }^{2}$ Adrien Baillet, Jugemens des sçavans sur les principaux ouvrages des auteurs (Paris, 1685), I, avertissement au lecteur, sig. avij verso; see Françoise Waquet, "Pour une éthique de la réception: les Jugemens des livres en général d'Adrien Baillet (1685)," XVIIe siècle, 159 (1988), 157-74. 
The perception of an overabundance of books fueled the production of many more books, often especially large ones, designed to remedy the problem-from new genres like the universal bibliography and the book review to new (or not-so-new) contributions to well-established genres, including the florilegium, the dictionary, and the encyclopedic compilation. Along with the alphabetical index these latter genres originated in the thirteenth century in response to similar pressures of overload, which were elegantly articulated for example in Vincent of Beauvais's preface to his four-volume Speculum maius (1255):

Since the multitude of books, the shortness of time and the slipperiness of memory do not allow all things which are written to be equally retained in the mind, I decided to reduce in one volume in a compendium and in summary order some flowers selected according to my talents from all the authors I was able to read. ${ }^{3}$

The premise of this study is that the experience of overabundance not only fostered the diffusion and development of various aids to learning or "reference genres"4 but also affected the way scholars worked, from reading and taking notes to composing books of their own. What I propose here is a preliminary survey of some of the methods of reading and note-taking deployed by early modern scholars under the pressures of too many books and too few resources, notably of time, memory or money.

Many of the methods for managing an abundance of texts have remained identifiable in one form or another from antiquity to the present day: they typically involve selecting, sorting, and storing, carried out in various combinations and with various motives and technologies. Similarly, many of the practical expedients I will mention here, from selective reading to the use of abbreviations or of notes taken by someone else, are neither new nor unique to the period in which I have chosen to study them. As we learn more, thanks to a growing wave of recent literature, about "reading for action" (as opposed to spiritual contemplation or leisure and entertainment), we will be able to assess more fully the existence of both long continuities and variations in time and

${ }^{3}$ Vincent of Beauvais, Bibliotheca mundi (Douai, 1624), I: Speculum naturale, Prologue, 1. See Serge Lusignan, Préface au Speculum maius de Vincent de Beauvais (Montreal, 1979).

${ }^{4}$ Although it dates from the nineteenth century, "reference book" is a convenient shorthand for describing a category of book that was recognized in the early modern period, and which is more evocative today than early modern equivalents such as "repertoire." See Olga Weijers, "Dictionnaires et autres répertoires," Méthodes et instruments du travail intellectuel au moyen âge. Etudes sur le vocabulaire, ed. Weijers (Turnhout, 1990), 197-208, and Gabriel Naudé, Advis pour dresser une bibliothèque (1627; repr. Leipzig, 1963), 51. 
place in the transmission of methods of scholary study and their associated shortcuts, from antiquity to the early modern period and beyond. ${ }^{5}$

My purpose is not to revisit claims for a reading revolution, or even a reading evolution. ${ }^{6}$ Indeed the "before" picture of any claim for changing reading practices in the early modern period would have to be complicated by the existence from the thirteenth century already not only of indexes and reference genres but also of features of textual lay-out that facilitated consultation: running heads at the tops of the pages of scholastic manuscripts, subdivisions of the text, into books, chapters, questions, distinctions, objections, often numbered and generally highlighted in some way on the page (e.g., through rubrication or the use of special initials). ${ }^{7}$ Rather than assuming that medieval reading consisted mainly of carefully "ruminating" a few memorized religious texts, it is safer (I propose) to assume that in most periods proficient readers have deployed a range of different kinds of reading in different circumstances. By the eighteenth century we have a well-studied case in point with Samuel Johnson who, in addition to reporting that he "read like a Turk by tearing the heart out of a book," when lying sleepless in bed, also used distinct terms to refer to at least four different ways of reading: "hard study" (which included taking notes), "perusal" (punctual consultation), "curious reading" (engrossed in a novel) and "mere reading" (browsing, as in journals). ${ }^{8}$

While Johnson's terminology is late for my chronological range, one finds similar and quite explicit distinctions made by Francis Bacon in his Essay "Of Studies" (1612):

Some books are to be tasted, others to be swallowed and some few to be chewed and digested; that is, some books are to be read only in

${ }^{5}$ See Lisa Jardine and Anthony Grafton, "Studied for Action: How Gabriel Harvey Read his Livy," Past and Present, 129 (1990), 30-78; William H. Sherman, John Dee: The Politics of Reading and Writing in the English Renaissance (Amherst, Mass., 1995) and Kevin Sharpe, Reading Revolutions: The Politics of Reading in Early Modern England (New Haven, Conn., 2000).

${ }^{6}$ See Rolf Engelsing, "Die Perioden der Lesergeschichte in der Neuzeit," Zur Sozialgeschichte deutscher Mittel- und Unterschichten (Göttingen, 1978²), 112-54; Reinhard Wittmann, "Was There a Reading Revolution at the End of the Eighteenth Century?" in A History of Reading in the West, ed. Guglielmo Cavallo and Roger Chartier, tr. Lydia G. Cochrane (Amherst, Mass., 1999), 284-312.

${ }^{7}$ See Mary Rouse and Richard Rouse, Authentic Witnesses: Approaches to Medieval Texts and Manuscripts (Notre Dame, 1991), esp. chs. 6-7; Mary Carruthers, The Book of Memory: A Study of Memory in Medieval Culture (Cambridge, 1990), and, more generally, Jacqueline Hamesse, "The Scholastic Model of Reading," in A History of Reading in the West, 103-19.

${ }^{8}$ These categories are developed in Robert DeMaria Jr., Samuel Johnson and the Life of Reading (Baltimore, 1997). "Reading like a Turk" is reported in Boswell's Life of Johnson, ed. G. B. Hill (6 vols.; Oxford, 1934), IV, 409; see Richard Yeo, Encyclopaedic Visions: Scientific Dictionaries and Enlightenment Culture (Cambridge, 2001), 90. 
parts; others to be read, but not curiously; and some few to be read wholly, and with diligence and attention. ${ }^{9}$

This passage lived on not only in the very many editions of Bacon's Essays but also in the Latin translation of it that Daniel Georg Morhof quoted approvingly at least twice in his massive Polyhistor, which appeared in five editions from 1687 to 1747 and appealed widely to students and scholars in the German world. ${ }^{10}$ Similar, if less elaborate distinctions, can be found among other humanists. ${ }^{11}$ This strategy involved selecting from a variety of ways of reading that approach which was most appropriate for each book.

This advice about reading widely and differentially rather than always thoroughly coexisted with equally long-lived advice to read carefully from a narrow canon of the "best books." Already Seneca had mocked those who collected more books than they could read and recommended focusing on a few well-tried authors. ${ }^{12}$ Petrarch alluded to Seneca when he drew up a list of some forty "favorite" books, to which he returned again and again, while he ventured into other books only, to use Seneca's words, "as a scout."13 The refrain of moralists was also that of religious educators. A book on how to read with profit by the Jesuit Francesco Sacchini (1614) was not only reprinted in many Latin editions, presumably for use by Jesuits, but also appealed to their archenemies in religion, judging from the dedication of the 1786 French translation of the work to a professor of theology at Geneva. ${ }^{14}$ Like that other Jesuit, Antonio Possevino, who recommended a select (and aggressively purged) rather than a

${ }^{9}$ Francis Bacon, "Of Studies" in Essays (1612) in Francis Bacon, ed. Brian Vickers (Oxford, 1996), 439. Vickers notes that "curiously" should be understood here from its root (cura): "with minute attention" (773).

${ }^{10}$ Reginald Walter Gibson, Francis Bacon: a Bibliography of his Works to 1750 (Oxford, 1959), xiii, lists 28 editions of the Essays to 1750. See Daniel Georg Morhof, Polyhistor (Lübeck, 1732), I, I, 2, \#9 (p. 14) and I, II, 8 \#20 (p. 409); see Mapping the World of Learning: The Polyhistor of Daniel Georg Morhof, ed. Françoise Waquet (Wiesbaden, 2000).

${ }^{11}$ For example, Beatus Rhenanus contrasted "degustare" with "diligentius perlegere" in ways of reading an ancient text; see Pierre Petitmengin, "La terminologie philologique de Beatus Rhenanus," Beatus Rhenanus. Lecteur et éditeur des textes anciens (Turnout, 2000), 195-222, 198.

${ }^{12}$ Seneca, Epistles, 2 and 45, and De tranquillitate animi, ch. 9, cited in Morhof, Polyhistor, I, I, ch. 3, \#4, p. 21.

${ }^{13}$ The list was radical in that almost all of the authors on it were pagan: "Libri mei peculiares. Ad reliquos non transfuga, sed explorator" (alluding to Seneca Ep. I, 2, 5); see B. L. Ullman, Studies in the Italian Renaissance (Rome, 1973), ch. 4, 113-33, 114.

${ }^{14}$ Franciscus Sacchini, De ratione libros cum profectu legendi libellus, composed in 1603 and first published in Würzburg, 1614, with reeditions in 1615, 1617, 1618, 1711, 1738, 1754, 1856, and 1866. Translated into French as Moyens de lire avec fruit (tr. Durey de Morsan) (La Haye, et se trouvent à Paris chez Guilot, 1786), dedicated to M. Claude Claparede, pasteur de l'Eglise de Genève et professeur en théologie. I am grateful to Helmut Zedelmaier for a copy of the 1614 edition; all citations are from this edition. 
universal library, ${ }^{15}$ Sacchini emphasized choosing and reading carefully a core of "good" books - by which he meant books that would further piety and the ancient classics which were to be read with great care.

I urge that when a young man finds himself with some free time, he conscientiously devote himself not to reading new books but rather to re-reading and going over attentively those books which he knows already from the guidance of his teacher.... It is much better in the beginning to learn a few things well, than to taste many things.... Therefore if you set out to read a book, order requires that you read it from beginning to end: in this way you will understand more easily and retain much better the whole subject of the book. ${ }^{16}$

Of course if the pedagogue protests so much about the importance of reading little but thoroughly and always to the end, one must suspect that his advice was perhaps often honored in the breach. Nonetheless in some quarters as late as the end of the eighteenth century the response to overabundance was to insist that young men, whose judgment and habits were still being formed, focus on close and repeated readings of a narrow canon of books. This stance complicates the "after" picture of claims for a generalized reading revolution in that period.

In practice one of the most immediate consequences of the increased availability of books was that libraries increased in size. To choose just a few results from among the growing numbers of studies of book ownership, a typical French royal magistrate in the late fifteenth century would have owned sixty books; one hundred years later Montaigne remarked that he owned about a thousand books, in what would have been an exceptionally large private library for the time; in the early eighteenth century another famous French provincial magistrate, Montesquieu, owned over three thousand books. ${ }^{17}$ Iconographical representations of scholars at work also provide evidence for an increase in the number of books they used. Early medieval depictions typically involve a scholar

${ }^{15}$ See Helmut Zedelmaier, Bibliotheca universalis, bibliotheca selecta: das Problem der Ordnung des Gelehrten Wissens in der frühen Neuzeit (Köln, 1992); and Luigi Balsamo, "How to Doctor a Bibliography: Antonio Possevino's Practice," Church, Censorship and Culture in Early Modern Italy, ed. Gigliola Fragnito (Cambridge, 2001), 50-79.

${ }^{16}$ Sacchini, 32, 41-42.

${ }^{17}$ See Geneviève Hasenohr, in Histoire des Bibliothèques Françaises, I: Les Bibliothèques médiévales, du VIe siècle à 1530, ed. André Vernet (Paris, 1988), 239; Peter Burke, A Social History of Knowledge 1500-1800. From Gutenberg to Diderot(Cambridge, 2000), 191-92; Louis Desgraves and Catherine Volpilhac-Auger, Catalogue de la Bibliothèque de Montesquieu à La Brède (Naples, 1999); Gilbert de Botton and Francis Pottiée-Sperry, "A la recherche de la 'librairie' de Montaigne," Bulletin du bibliophile, 2 (1997), 254-80, and Montaigne, Essais, ed. Pierre Villey (Paris, 1988), III, 12, p. 1056. I am grateful to George Hoffman for his expertise on Montaigne. 
reading one text. One historian notes that there are no depictions of scholars with multiple texts open simultaneously until 1200 and these are not common until $1400 .{ }^{18}$ Early modern paintings of scholars on the other hand usually depict many open and closed books and manuscripts spread out on desk, shelves, and floor, even to the point of messiness. ${ }^{19}$ Although book ownership and iconographical depictions certainly do not suffice as evidence of reading, they do indicate that scholars surrounded themselves with increasingly more books.

In addition to owning more books, one can surmise that scholars did their best to read more of them. The first method for doing so was to apply ever more diligence and hard work. A common refrain of humanist prefaces and title pages was to emphasize the "very great labors and sleepless nights" required and the many obstacles and difficulties (financial and physical) overcome in completing the work. ${ }^{20}$ The call for diligence only became more explicit in the seventeenth century, as many scholars bemoaned what they perceived as a decline of learning since ca. 1600, which they blamed on the increasing use of shortcuts and reference genres of the various kinds. These authors called instead for a renewal of the traditional methods of "hard study." Thus Meric Casaubon in a manuscript on "Generall Learning" explains that instead of turning to fancy methods from Ramism to Cartesianism which promised "a shorter way," "the best method to learning ... is indefatigable (soe farr as the bodie will beare) industrie, and assiduitie, in reading good authors, such as have had the approbation of all learned ages. ${ }^{21}$ Even the authors and proponents of manuals and other aids would not deny the importance of diligence. Thus Johann Heinrich Alsted (Alstedius), the author of a massive Encyclopedia (1630), earned the anagrammatic nickname of "sedulitas" - conscientiousness - for one of the virtues he held most dear. ${ }^{22}$ But there were inevitably limits to simply stepping up the program of hard study, whence the shortcuts that were devised.

${ }^{18}$ Jocelyn Penny Small, Wax Tablets of the Mind: Cognitive Studies of Memory and Literacy in Classical Antiquity (London, 1997), 168.

${ }^{19}$ See John Willis Clark, The Care of Books: An Essay on the Development of Libraries and their Fittings, from the Earliest Times to the End of the Eighteenth Century (Cambridge, 1901), 295-97; and Dora Thornton, The Scholar in his Study: Ownership and Experience in Renaissance Italy (New Haven, Conn., 1997).

${ }^{20}$ See the title page of Erasmus, Adagiorum chiliades tres (Venice, 1508) "summis certe laboribus summis vigiliis."

${ }^{21}$ Meric Casaubon, Generall Learning, ed. Richard Serjeantson (Cambridge, 1999), 177. See also Mordechai Feingold, "English Ramism: A Reinterpretation," The Influence of Petrus Ramus: Studies in Sixteenth and Seventeenth Century Philosophy and Sciences, ed. Mordechai Feingold et al. (Basel, 2001), 127-76, e.g., 160-64; and Mordechai Feingold, "The Humanities," The History of the University of Oxford, IV, ed. Nicholas Tyacke (Oxford, 1997), 211-357, esp. 218-21, 240.

${ }^{22}$ Howard Hotson, Johann Heinrich Alsted (1588-1638): Between Renaissance, Reformation and Universal Reform (Oxford, 2000), 8. 


\section{Reading in Parts}

How can we know when a book was read "only in parts" as Bacon recommends? Marginal annotations which do not run continuously from the beginning to some ending point but are clustered here and there may indicate that readers only read specific parts of a book, although one can never be sure that the annotated parts were the only ones that the annotator read. One can of course suppose from their form that large folio books divided into chapters or topical headings and equipped with alphabetical indexes would be read punctually rather than straight through. Other books could also be read on a consultation basis and one could also read a dictionary or an encyclopedia from cover to cover. Therefore form alone does not dictate use and firm evidence about what may be called consultation reading is hard to come by.

Occasionally authors expressed the expectation that their work would be consulted rather than read through. The first such instance I have found so far is Conrad Gesner, who explains in justifying the alphabetical arrangement of his Historia animalium (1551) that the "utility of lexica" like his "comes not from reading it from beginning to end, which would be more tedious than useful, but from consulting it from time to time" (ut consulat ea per intervalla). ${ }^{23}$ Here we find the classical Latin term "consulere," typically applied to the consultation of people or oracles for advice, being applied to books. As if he were conscious of the need to specify better what he means because he is using the term in an unusual way, Gesner adds "per intervalla" to make the intermittent and nonsequential nature of the reading he is describing quite clear. As Richard Yeo's article here highlights, the term seemed unproblematic some 150 years later, to John Harris who boasted that his Lexicon technicum was not only easy to consult occasionally but also good to "read carefully over."

The best evidence I have found of the desire of early modern readers to engage in consultation reading is the considerable attention they devoted to the indexing of books, whether by compiling their own indexes or by correcting and completing the indexes supplied by printers. ${ }^{24}$ One of the main functions of marginal annotations made in early modern books was to flag the topics treated in the text, to be able to find one's way back to a particular passage. The most

${ }^{23}$ Conrad Gesner, Historiae Animalium lib. I de Quadrupedibus viviparis (Zurich, 1551), sig. beta $1^{\mathrm{v}}$.

${ }^{24}$ See my "Annotating and Indexing Natural Philosophy," Books and the Sciences in History, ed. Marina Frasca-Spada and Nick Jardine (Cambridge, 2000), 69-89; Circuler et Naviguer ou les index à l'époque humaniste, Nugae humanisticae sub insigno Erasmi, ed. Alexandre Vanautgaerden (Brussels, 2001); Fabula in Tabula. Una storia degli indici dal manoscritto al testo elettronico, ed. Claudio Leonardi, Marcello Morelli, and Francesco Santi (Spoleto, 1995); and Helmut Zedelmaier, "Facilitas inveniendi. Zur Pragmatik alphabetischer Register," forthcoming in a volume ed. Colloquia Augustana. 
interesting topics might then be gathered by page number in the fly-leaf. ${ }^{25}$ Of course a manuscript index could only serve to guide the reader back to a passage he had already read, but indexes supplied by the printer were especially precious for finding new information, as Gesner notes in recommending the practice and giving advice on how to index a book efficiently. ${ }^{26}$ Readers might even expend considerable effort improving on the indexes provided in print. Thus one reader of the 1508 edition of Erasmus's Adages was evidently frustrated with the miscellaneous arrangement of the commonplace headings under which the adages were sorted in the "second index" provided in print. In this case "index" designated a finding device but one which was not alphabetically but miscellaneously arranged: the reader would scan a simple list of 257 headings to locate the one of interest and then turn to the list reproduced in the same order complete with the references to the text to find a relevant adage. But this reader wanted to locate a commonplace heading and corresponding adage more efficiently, and to do so drew up in manuscript an alphabetical index to the printed "second index" by numbering each commonplace heading in the order of its appearance in that jumbled list, then alphabetizing the headings and providing for each its order number as a finding device in the printed "second index." ${ }^{27}$ Later editions of the Adages supplied in print an equivalent, though more cumbersome, finding aid to the jumbled "second index."28

Printers understood the demand of readers for indexes, even if they did not always satisfy it. Title pages boasted of a "most complete" or "augmented and corrected" index or indexes, even occasionally when the index was actually missing due to unexpected difficulties. ${ }^{29}$ The alphabetical index was particularly important in large reference works. Typically present from the first edition, the index served, I would argue, as the principal mode of access to works arranged systematically or miscellaneously; the miscellany was favored by a number of learned authors in the Renaissance, typically in works that originated as commentaries, such as Erasmus's Adages or Caelius Rhodiginus's

${ }^{25}$ See the reproductions from my The Theater of Nature: Jean Bodin and Renaissance Science (Princeton, 1997), 196-97, and, more generally, William Sherman, "What Did Renaissance Readers Write in Their Books?" Books and Readers in Early Modern England, ed. Jennifer Andersen and Elizabeth Sauer (Cambridge, 2002), 119-37.

${ }^{26}$ Conrad Gesner, Pandectae (Zurich, 1548), titulus xiii, part 2, f. 19v, "Mihi profecto in vita tam brevi et tanta studiorum varietate versantibus necessarij videntur librorum indices, non minus quam in trivio Mercurius, sive ut reminiscatur quae quis legerit, sive ut nova primum inveniat."

${ }^{27}$ See the copy of Erasmus, Adagiorum chiliades tres (Venice, 1508) in Houghton Library, *fNC5.Er153.A2.1508. See Ann Blair, "Corrections manuscrites et listes d'errata à la Renaissance," in Mélanges Jean Céard, ed. Jean Dupèbe and Franco Giacone (forthcoming).

${ }^{28}$ In the Basel edition of 1515, the original jumbled "second index" is supplied with column numbers to which an alphabetized list of the commonplace headings refer.

${ }^{29}$ See, for example, Theodor Zwinger, Theatrum vitae humanae (Basel, 1565), which includes an apology for the missing index. 
Lectiones antiquae (1516). ${ }^{30}$ It is not unusual to find the bulk of the annotations in these kinds of works clustered in the index: corrections of page references, additions of items omitted, or re-alphabetization of an item under a new keyword where the reader would have expected to find it. These annotations of finding devices both record the results of a reading of a book "in parts" and show the concern of readers to facilitate future uses of this kind. ${ }^{31}$

\section{Shortcuts in Note-Taking}

According to all the advice books, reading for study or to acquire information or knowledge was supposed to include note-taking. In one of the most widely diffused manuals on note-taking, the Jesuit Jeremias Drexel explained: "Reading is useless, vain and silly when no writing is involved, unless you are reading [devotionally] Thomas a Kempis or some such. Although I would not want even that kind of reading to be devoid of all note-taking." 32 Drexel does not specify how one should take notes when reading for spiritual purposes, but Drexel and a number of other manuals from the seventeenth century focus on how students should take notes in reading ancient and modern authors in various disciplines, from rhetoric and history to mathematics and politics. ${ }^{33}$ This process of "excerpting" was said to aid the memory in at least two ways: the act of writing itself helped to ingrain the passage in the memory, and the excerpts could then be learned by heart to exercise the memory. ${ }^{34}$

The notes could take many forms. Francis Bacon explained succinctly that notes could be made either "by epitome or abridgement" (that is, by paraphrasing the source) or "by heads or commonplaces" (that is, by copying a passage and storing it in a notebook under a commonplace heading for later retrieval and use). Bacon considered the latter method "of far more profit and use." 35

${ }^{30}$ See my contribution to Der Kommentar in der frühen Neuzeit, ed. Ralph Häfner and Markus Völkel, forthcoming.

${ }^{31}$ Another kind of evidence for the widespread use of indexes, which I will not pursue here, includes complaints about their use, from Drexel's strictures against those young men who hope to find all they need through indexes to Jonathan Swift's mocking of "index-learning." See Drexel (note 32), 72-73, and Richard Yeo's article below for Swift.

32 Jeremias Drexel, S.J., Aurifodina artium et scientiarum omnium; excerpendi sollertia, omnibus litterarum amantibus monstrata (Antwerp, 1638), 72, "Otiosa, vana, nugatoria est lectio, cui nulla miscetur scriptio. Nisi Thomam Kempensem aut similes legas. Quamvis nec hanc quidem lectionem velim annotationis omnis expertem." See Florian Neumann, "Jeremias Drexels Aurifodina und die Ars Excerpendi bei den Jesuiten," in Die Praktiken der Gelehrsamkeit in der Frühen Neuzeit, ed. Helmut Zedelmaier and Martin Mulsow (Tübingen, 2001), 51-62. See Helmut Zedelmaier, "Johann Jakob Moser und die gelehrte Wissensverwaltung in der Frühen Neuzeit," forthcoming in a volume ed. Elizabeth Décultot.

${ }^{33}$ Drexel, Part I, ch. 8, on including things heard and seen as well as read, see Drexel, sig. $\mathrm{A} 7^{\mathrm{v}}$.

${ }^{34}$ Sacchini, 75; Drexel, 84.

${ }^{35}$ Vernon F. Snow, "Francis Bacon's Advice to Fulke Greville on Research Techniques," Huntington Library Quarterly, 23 (1960), 369-79, 370. 
The seventeenth-century German academic context was especially fertile in detailed descriptions of excerpting methods in which each author was proud to contribute his personal variations. The Jesuit Drexel, for example, described three kinds of notes, which were to be kept in separate quarto notebooks, each with its own alphabetical index in octavo format. Lemmata contained precise bibliographical references relevant to a topic, along with a brief assessment of the interest of the works cited, but without any quotation from or paraphrase of the text. Secondly, adversaria were devoted for example to "ancient rituals, epitaphs, notable descriptions, sententiae or sayings explained in more detail, [that were] rare, admirable, new or old." Finally, historica gathered historical exempla described in more or less detail. ${ }^{36}$ Drexel did not seem to distinguish between direct quotations or paraphrases and acknowledged that the reader might prefer to devise his own system: "if you do not like these precepts and rules, write others for yourself ... that suit your studies. ${ }^{\prime 37}$ The most important thing, for Drexel, was simply to take notes, regardless of their form.

Sacchini, the superdiligent Jesuit, favored copying out passages twice, once in a notebook kept in the order in which the passages were encountered in the text, and a second time to sort them under appropriate topical headings - just as careful merchants, he added, draw up tables of their affairs. ${ }^{38}$ Even more elaborate was the system described by Vincent Placcius, not a Jesuit but a professor at Hamburg. In his De arte excerpendi (1689) Placcius published an anonymous manuscript (now in the British Library) describing an "arca studiorum" and presented his own improvements for this note-storage closet. ${ }^{39}$ Placcius would take notes on slips of paper which he stored in a specialscrinium literatum ("literary chest") built for the purpose, in which the slips were stuck onto hooks labelled with topical headings. Placcius's preference for slips of paper over the usual bound notebooks is quite unique, although moveable slips had occasionally been recommended as a temporary tool in the preparation of an index or a notebook. ${ }^{40}$ Placcius praised his scrinium especially for making all of his material visible in one glance and for the ease with which the slips

${ }^{36}$ Drexel, Part II, ch. 3, 85-87.

${ }^{37}$ Drexel, sig. A7v, "Quod si praeceptiones istae et excerpendi leges non placeant, scribe tibi alias, pauciores, breviores, studiis tuis commodas, dummodo excerpas."

${ }^{38}$ Sacchini, 90-91. The parallels between scholarly note-taking and other forms of recordkeeping, by merchants, lawyers or government officials, are well worth pursuing. See Anke te Heesen, "Die dopplete Verzeichnung. Schriftliche und räumliche Aneignungsweisen von Natur im 18. Jahrhundert," Max Planck Institut für Wissenschaftsgeschichte, preprint 204 (2002).

${ }^{39}$ British Library MS Add. 41,846, ca. 1637, from the Kenelm Digby Papers. See Christoph Meinel, "Enzyklopädie der Welt und Verzettelung des Wissens: Aporien der Empirie bei Joachim Jungius," Enzyklopädien der frühen Neuzeit, ed. Franz M. Eybl et al. (Tübingen, 1995), 162-87, 181.

${ }^{40}$ Meinel, 169-75. For another elaborate method of note-taking, see Klaus Weimar, "Johann Caspar Hagenbuchs 'Gelehrte Buchhalterey,' ” forthcoming in a volume ed. Elisabeth Décultot. 
could be shifted between different categories. ${ }^{41}$ Placcius's system did not suffer from the usual problems associated with notebooks: gauging the amount of blank space to leave for future entries under a given heading and then running out of space, or wanting to change the heading under which an entry had been made without having to copy it out again..$^{42}$ Placcius also liked using the scrinium for interfiling with his notes the many printed pamphlets, "programs, fragments of books or disputations of others" which the German academic life generated in such abundance. ${ }^{43}$

Although Leibniz reportedly had a scrinium made according to Placcius's instructions, the cost and energy required to construct such a note-storage device was beyond the abilities of most. ${ }^{44}$ Placcius's autobiographical appendix to his manual indeed reveals his extraordinary dedication to taking and sorting notes in a lifetime devoted to making indexes and tables, compiling bibliographies, quotations and wordlists, yielding a total of 72 different works. All of these were left in manuscript except Placcius's bibliography of pseudonymous and anonymous works, first published in 1674, which became a well-known reference book as the Theatrum anonymorum et pseudonymorum, enlarged and published posthumously in $1708 .{ }^{45}$

Without going to such unusual lengths as Placcius or even Sacchini, notetaking was clearly a very time-consuming practice and an aspect of reading for which shortcuts would be of particular help. One shortcut was to rely on notes taken by someone else, whether by an amanuensis hired for the purpose or by the author or compiler of those printed aids which offered notes precisely of the kind one might have taken oneself, notably epitomes and commonplace books or florilegia. Advice-givers frequently condemned the use of notes by another as of little benefit since notes served primarily to jog the note-taker's memory. At the same time most manuals also assumed that their readers would be familiar with such aids. Thus Bacon offers recommendations on how to select "your gatherers" and "abridgers," observing for example that "the great clerks are not always the wisest men." ${ }^{46}$ Morhof encouraged the practice: if you can afford it, employ "learned amanuenses, who use your judgment in

${ }^{41}$ Vincent Placcius, De arte excerpendi, vom Gelährten Buchhalten liber singularis quo genera et praecepta excerpendi (Stockholm, 1689), 70, 159. Some of Placcius's illustrations of the scrinium are reproduced in Meinel.

${ }^{42}$ For another solution to these difficulties, see John Locke, "Nouvelle méthode de dresser des recueils," Bibliothèque universelle et historique (1686), II, 315-40.

${ }^{43}$ Placcius, 157.

${ }^{44}$ Von Murr, "Von Leibnitzens Exzerpirschrank" Journal zur Kunstgeschichte und allgemeinen Litteratur, 7 (1779) Nürnberg, 210-2; cited in Meinel, 182.

${ }^{45}$ Vincent Placcius, De scriptis et scriptoribus anonymis atque pseudonymis syntagma (Hamburg, 1674). See Martin Mulsow, "Practices of Unmasking: Polyhistors, Correspondence, and the Birth of Dictionaries of Pseudonymity in Seventeenth-Century Germany," forthcoming.

${ }^{46}$ Snow, "Bacon's Advice," 374. 
collecting, as Saumaise and other very eminent men have done." ${ }^{47}$ Gabriel Harvey provides a rich example of a "facilitator" of this kind, whose abundant marginal summaries and comments were meant to be circulated in the circle of his patron. ${ }^{48}$ Other forms of reliance on the work of others involved groups of readers, such as students or a literary society, dividing the task of note-taking among themselves, assigning to each different books or different themes to excerpt. ${ }^{49}$

As for the ready-made printed aids, whether they were considered useful tools, necessary evils, or the cause of the downfall of civilization, they certainly were often reprinted..$^{50}$ Gabriel Naudé was one of the most enthusiastic advocates of reference works, recommending their purchase for any library: "I esteem these Collections extreamly profitable and necessary, considering, the brevity of our life, and the multitude of things which we are now obliged to know, e're one can be reckoned amongst the number of learned men, do not permit us to do all of ourselves." 51 Others saw in such aids only the decline of true learning: "So many summaries, so many new methods, so many indexes, so many dictionaries have slowed the live ardor which made men learned.... All the sciences today are reduced to dictionaries and no one seeks other keys to enter them." ${ }^{52}$ Critics and enthusiasts alike recorded the widespread use of such tools. Naudé reported, for example, how a learned man of considerable repute copied out a discussion of a difficult word he had encountered from one of the fifty "dictionaries" of all kinds that he owned and

transcribed out of it above a page of writing ... and that in the presence of a certain Friend of mine and of his; to whom he could not abstain from saying, that those who should see this remark, would easily be-

${ }^{47}$ Morhof, I, 1, 21 \#12, p. 239, "Vel si opibus non destituaris, amanuenses alas non ineruditos, quibus rem illam committas; sed qui tuo judicio in colligendo utantur. Id Salmasius aliique viri praestantissimi fecerunt."

48 Jardine and Grafton, "Studied for Action."

${ }^{49}$ Placcius, 146, 161-62. Placcius mentions Keckermann as the first to write "de excerptis socialibus" in Cons. log. de adornandis locis communibus, c. 1. p. 3 col. 2; and on the Magdeburg Centuries, see Anthony Grafton, "Where was Salomon's House? Ecclesiastical History and the Intellectual Origins of Bacon's New Atlantis," in Die europäische Gelehrtenrepublik im Zeitalter des Konfessionalismus, ed. Herbert Jaumann (Wiesbaden, 2001), 21-38.

${ }^{50}$ For example, Domenico Nani Mirabelli, Polyanthea (1503), in at least 26 editions to 1681. Caelius Rhodiginus, Lectiones antiquae (1516), then 10 editions to 1666; Ambrogio Calepino, Dictionarium (1503), then 150 editions to 1785; Theodor Zwinger, Theatrum Humanae Vitae (1565) in 4 editions to 1604 and forming the basis of Laurentius Beyerlinck, Magnum Theatrum Humanae Vitae (1631), in 5 editions to 1707, each of which comprised 8 folio volumes.

${ }^{51}$ Gabriel Naudé, Instructions concerning erecting of a library, tr. John Evelyn (1661; repr. Cambridge, Mass., 1903), 60-61.

${ }^{52}$ Huetiana ou pensées diverses de M. Huet (Paris, 1722), \#74, p. 171. 
lieve that he had spent above two dayes in composing it; though he had in truth but the pains onely of transcribing it. ${ }^{53}$

Although Naudé signals by his carefully anonymous account that this behavior was considered shameful in some respects, he also praises reference books as time-saving devices.

Jeremias Drexel on the contrary noted the incompleteness and errors of reference books, which typically omitted page and chapter numbers, mutilated passages and names, and relied only on a few authors, and he complained of their great expense - 70 florins, he exclaimed, for the exceptionally large Magnum theatrum vitae of 1631, not to mention binding costs-for little return. ${ }^{54}$ "In these volumes you least find what you most are looking for ... You will drink much more sweetly and much more safely from the source itself, even if you drink less." 55 At the same time Drexel also assumed that his reader would have a few such volumes handy, as he challenged him to find in them the headings that Drexel had in his own notebooks. ${ }^{56}$ Indeed from its earliest years the Collegio Romano, model for all Jesuit colleges, was instructed to stock a range of such works, including dictionaries, florilegia and works of encyclopedic erudition like Rhodiginus's Lectiones antiquae, alongside classroom texts and ecclesiastical and secular historians, so that students could work from them on building their collections of excerpts during periods of private study. ${ }^{57}$ These printed aids spared their users the labor and time of selecting noteworthy passages in various sources and of assigning appropriate headings, but their use involved copying out the passage into a manuscript, whether a personal notebook or, as in the example Naudé described, lecture notes or a composition which might be one step closer to potential publication.

Greater speed in note-taking could be achieved by the use of abbreviations made in notebooks and especially in the margins of books. Different colors of ink used in flagging passages with lines in the text or the margins might be used to signify different kinds of passages.$^{58}$ Placcius praised abbreviations noted in the margins, such as v.gr., N.B., obj, resp, as being "of no small use," but he

${ }^{53}$ Naudé, Instructions, 60.

${ }^{54}$ Drexel, $139-40$.

${ }^{55}$ Drexel, 139; "Longe suavius, longeque tutius ex ipso fonte bibes, tametsi parcius bibas. In illis voluminibus id plerumque minime invenies, quod maxime quaersieris." Drexel is repeating a complaint he had also used against indexes (see p. 73).

56 "Abi modo et scrutare tuos illos codices ..." Drexel, 140.

${ }^{57}$ Paul Nelles, "Lectio, repetitio, Memoria. Monks, Books and Jesuit Note-taking 154865," conference paper delivered at "The Jesuits II: Cultures, Sciences, and the Arts, 1540-1773," 5-9 June 2002, citing Monumenta Paedagogica Societatis Jesu, ed. L. Lukács (7 vols.; Rome, 1965-), II, 76, 557-58.

${ }^{58}$ See Anthony Grafton, Bring Out Your Dead: the Past as Revelation (Cambridge, 2002), 2 n. 5. 
distinguished them explicitly from excerpting which they were not meant to replace. ${ }^{59}$ The French royal historiographer Charles Sorel, on the other hand, offered detailed advice on how to rely primarily on abbreviations in taking notes. Scholars, Sorel explained, valued their time and left the keeping of commonplace notebooks to schoolboys for whom it was good exercise; "hommes d'études" would at most transcribe the reference to a passage in a notebook (as in Drexel's lemmata) and refrained from copying out whole passages except for those books which they did not own and could not keep. ${ }^{60}$ Sorel noted that these time-saving devices would also appeal to those (more likely to be among the readers of his vernacular book) who found themselves engrossed in the pleasure of reading and who did not wish to interrupt it to take notes. ${ }^{61}$ Sorel explained how to reduce words or expressions to one or two letters or symbols, how to flag a passage by underlining it or making a mark in the margin. "The greatest secret" was to make different marks for different kinds of passages: "crosses, circles, half-circles, numbers, letters and other characters which had the various meanings one had assigned to them." 62 In this way a scholar could review a book in a half-hour that would have taken four or five days to read. ${ }^{63}$ Sorel confidently expected the scholar even twenty years later to recognize the symbols and the thoughts that had prompted them. Whether this was the case or not, historians who encounter these kinds of notes certainly can most often no longer reconstruct their meaning. ${ }^{64}$ Only occasionally did the users of such abbreviations leave a key to the symbols they devised. ${ }^{65}$

Two other forms of abbreviated note-taking spared the reader even the use of a pen. Isaac Newton was apparently unique in his practice of dog-earing, turning the corner of a page to point to a passage of interest in the text.6 ${ }^{6}$ Sacchini noted that some readers left slips of paper as bookmarks between the pages, but he especially railed against the practice of marking a passage with the fingernail, which he and Drexel condemned as shameful and damaging to the book;

${ }^{59}$ Placcius, 7.

${ }^{60}$ Charles Sorel, Supplement des traitez de la connoissance des bons livres (Paris, 1673), 12.

${ }^{61}$ Sorel, Supplement, 9; see also Drexel, 74.

${ }^{62}$ Sorel, Supplement, 9-10, 13.

${ }^{63}$ Sorel, Supplement, 12, "Cela est de grande utilité quand mesme avec cela on feroit des Recueils ou des Tables, pource qu'en moins d'une demy-heure, un homme fait la reveue d'un Livre dont la lecture entiere luy auroit couté quatre ou cinq jours."

${ }^{64}$ See Anthony Grafton, "How Guillaume Budé read his Homer," Commerce with the Classics: Ancient Books and Renaissance Readers (Ann Arbor, Mich., 1997), 135-83, 152ff; and Roger Stoddard, Marks in Books, Illustrated and Explained (Cambridge, Mass., 1985); Helen Jackson, Marginalia: Readers Writing in Books (New Haven, Conn., 2001); and William H. Sherman, Used Books: Reading Renaissance Marginalia, forthcoming.

${ }^{65}$ See William Sherman, “' Rather soiled by use': Renaissance Readers and Modern Collectors," The Reader Revealed, ed. Sabrina Alcorn Baron (Washington, D.C., 2001), 84-91.

${ }^{66}$ John Harrison, The Library of Isaac Newton (Cambridge, 1978), 26; for an illustration, see Scott Mandelbrote, Footprints of the Lion: Isaac Newton at Work (Cambridge, 2001), 43. 
Placcius's repetition of Drexel's condemnation seems somewhat less forceful. ${ }^{67}$ The practice, which is probably difficult to document today, was widespread enough to warrant not only these condemnations, but, in the eighteenth century, satirical references to ladies who "cherished [their] nails for the convenience of making marginal notes." ${ }^{68}$

Far more destructive to the printed book was a practice of note-taking or composing that involved cutting from the printed page to save the labor of copying from it. Although this method of book use was certainly not the norm and appealed particularly to compilers and those who composed many or very large books, the literal cutting and pasting from books was not unheard-of in the early modern period. The cheapening of books through printing and especially the potential for the accumulation of long unsold copies of printed books in the houses of authors, printers, or booksellers presumably contributed to making this destructive use financially practicable, although the practice might also be considered to have medieval antecedents, for example in the use of old manuscript leaves in bindings. ${ }^{69}$ A parallel use of cutting and pasting to transfer images, for example to replace a faulty image with a corrected one or to display an image outside its original format, would also require study, but it involves a somewhat different set of constraints and motivations. ${ }^{70}$

Conrad Gesner is the first major user of the cut-and-paste method that I have found so far. He describes cutting up the letters he received in order to distribute them among his papers according to their subject; as a result, he explained to a correspondent, he could not return to a letter to respond to it a second time. ${ }^{71}$ Similarly, he advocated taking notes for index entries on slips of paper which could be rearranged, either tucked under a string or pasted lightly until the final arrangement was reached and would then be pasted more permanently. In his advice on how to draw up an index, published in 1548, Gesner also explains that the contents of the slips need not always be copied out by

${ }^{67}$ See Sacchini, 64; Drexel, 72; Placcius, 5.

${ }^{68}$ Richard Brinsley Sheridan, The Rivals, ed. Elizabeth Duthie (London, 1979), Act I, scene 2, 19. I am grateful to Leah Price for this reference.

${ }^{69}$ See E. Ph. Goldschmidt, Gothic and Renaissance Bookbindings (London, 1928), I, 11922. See, more generally, Christopher de Hamel, Cutting Up Manuscripts for Pleasure and Profit, The 1995 Sol M. Malkin Lecture in Bibliography (Charlottesville, Va., 1998).

${ }^{70}$ See Oronce Finé, La théorique des cieux et sept planètes (Paris, 1557). Also, for imprints that were designed to be cut up, see Andrea Carlino, Paper Bodies: A Catalogue of Anatomical Fugitive Sheets 1538-1687, tr. Noga Arikha (London, 1999); Owen Gingerich, "Astronomical Paper Instruments with Moving Parts," in Making Instruments Count. Essays on Historical Scientific Instruments presented to Gerard L'Estrange Turner, ed. R. G. W. Anderson et al. (Aldershot, 1993), 63-74; and Sten Lindberg, "Mobiles in Books: Volvelles, inserts, pyramids, divinations and children's games," tr. William S. Mitchell, The Private Library, 2 (1979), 49-82.

${ }^{71}$ Gesner to Bauhin, 14 Nov. 1563 in Gesner, Vingt lettres à Jean Bauhin fils (1563-1565), tr. Augustin Sabot, ed. Claude Longeon (Saint-Etienne, 1976), 28, 71. I am grateful to Brian Ogilvie for this reference. 
hand but can be "citations of authors which have been cut out of other books. For this purpose two copies [of the book] are needed.... By this method where it is possible, one can really achieve many shortcuts of labor and various advantages to studies." 72

We can support the hypothesis that Gesner was describing here one of the ways in which he himself worked in compiling his massive bibliography and associated Pandectae from his own annotated copy of his Bibliotheca universalis. This Handexemplar evidently represents a state of the printed book prior to its final publication; on pp. 454-55 two sections of printed text have been cut from their original sheets and pasted into the bottom margin; they appear on those pages in the final, widely diffused version of the book. The manuscript annotations made in the Handexemplar, however, were often not integrated into the final version. ${ }^{73}$ The same method was used in the continuation of Gesner's bibliographical project, notably in an interleaved copy of the 1583 Bibliotheca of Johann Jakob Frisius. In addition to manuscript additions, the interleaved pages included a paste-in of the printed tabular presentation of the contents of a book by François Hotman. The intention was presumably for this material to be copied over in the next edition of the work, although none ever appeared. ${ }^{74}$ Saving the labor of copying was clearly a prime concern for Gesner and his successors in his massive project of managing information about books.

The prolific Italian polymath Girolamo Cardano also recommended cutting and pasting to "put a book in order fast": cut out the pieces of text (presumably from the manuscript one has composed, possibly from a preliminary printed version) in order to rearrange them into the desirable order, then paste them; "in this way you can accomplish in three days what could take a year to transcribe." 75 Cardano was so proud of this device that he called attention to it in the index to his De subtilitate. In another hint of some practice of this kind, Ulisse Aldrovandi, who managed a vast collection not only of natural objects but also of notes from books, thanked his wife for putting together his five-

${ }^{72}$ Conrad Gesner, Pandectae, fol. 20" , as translated in Hans Wellisch, "How to Index a Book-Sixteenth-Century Style: Conrad Gessner on Indexes and Catalogs," International Classification, 8 (1981), 10-15, 12.

${ }^{73}$ See Gesner, Bibliotheca universalis, ff. $454^{\mathrm{v}}-55^{\mathrm{r}}$, copy at the Zentralbibliothek, Zurich, $\operatorname{Dr}$ M 3, as compared with the copies of the book at Houghton Library and that used for the reprint edition (Osnabrück, 1966).

${ }^{74}$ See Bibliotheca instituta et collecta ... amplificata per Johannem Frisium (Zurich, 1583), copy at the Zentralbibliothek, Zurich, Ms Car XII 14. I have not yet been able to identify the work by Hotman.

${ }^{75}$ Cardano, De subtilitate (Basel, 1582), book 17, 503, "Ita tridui labore totum librum melius in ordinem ac facilius rediges, quam si toto anno transcribendo laborasses"; and see Opera Omnia (Lyon, 1663), III, 626 as discussed in Nancy Siraisi, The Clock and the Mirror: Girolamo Cardano and Renaissance Medicine (Princeton, 1997), 18; and in Anthony Grafton, Cardano's Cosmos: The Worlds and Works of a Renaissance Astrologer (Cambridge, 1999), 4. 
volume Lexicon of Inanimate Things. Most likely this meant arranging and fastening in the correct order for the printer a vast number of notes on slips of paper, such as those she also contributed to taking for her husband's Pandechion Epistomonicon, which collected passages from ancient and modern authorities on natural historical topics. ${ }^{76}$ Both cases involved primarily or exclusively passages cut and pasted from personal manuscript notes. But a century later the notebooks that survive of the bibliophile Jean-Nicolas de Tralage contained paste-ins of manuscript slips as well as occasional printed pages, like the title page of a 1666 book, which was either torn out of a copy of the printed book or perhaps procured from the printer or bookseller who may have stocked extra copies of the title page for advertisement purposes. ${ }^{77}$ Other examples of personal notebooks intermixing manuscript notes with passages cut from printed books are currently being studied. ${ }^{78}$

Compilers of large reference works, like Theodor Zwinger's Theatrum Humanae Vitae, which started in 1565 at 1400 folio pages and grew fivefold by 1604 , were no doubt particularly prone to the use of such shortcuts. Whether he had firm evidence for the claim or was relying only on a rational reconstruction of Zwinger's working methods, Samuel Hartlib's assessment seems quite plausible when he wrote in his diary in 1641, "Zwinger made his excerpta by being vsing of old bookes and tearing whole leaves out of them, otherwise it had beene impossible to have written so much if every thing should have beene written or copied out." ${ }^{79}$ Certainly the cutting and pasting of printed books was not unthinkable in Hartlib's context. Nor was it some one hundred years later, when William Smellie compiled the bulk of the first edition of the Encyclopedia Britannica (3 vols., 1768-71), though he deprecated that activity in describing it in cut-and paste terms: "but he [Smellie] held Dictionary making in great contempt; and used to say jocularly, that he had made a Dictionary of Arts and Sciences with a pair of scissors, clipping out from various book a quantum sufficit of matter for the printer." 80

${ }^{76}$ See Paula Findlen, "Masculine Prerogatives: Gender, Space, and Knowledge in the Early Modern Museum," in The Architecture of Science, ed. Peter Galison and Emily Thompson (Cambridge, 1999), 29-57, 44 and n. 62.

${ }^{77}$ Bernardin Surius, Le pieux pelerin ou voyage de Jerusalem (Brussels, 1666); see the recueil of Jean-Nicolas de Tralage, Bibliothèque Mazarine, Ms 4299, page marked "Nomb. 68"

${ }^{78}$ These include the mid-seventeenth-century commonplace books of the royalist Sir John Gibson, studied by Adam Smyth in Printed Miscellanies in England, 1640-1682 (forthcoming, Detroit, 2003); and the Jesuit Claude-François Menestrier, whose notebooks Judi Loach (University of Cardiff) is studying.

79 "The Hartlib Papers," ed. Hartlib Papers Project, Judith Crawford et al. (Ann Arbor, Mich., 1995), Ephemerides, 1641, "ars excerpendi."

${ }^{80}$ Robert Kerr, Memoirs of the Life, Writings and Correspondence of William Smellie (2 vols.; Edinburgh, 1811), I, 362-63 (emphases in the original), and see Richard Yeo, Encyclopaedic Visions, 180. 
Cutting and pasting probably only became more prevalent in the modern period. The cheap newspaper, for example, destined for the trash, prompted the collection of newspaper clippings. ${ }^{81}$ And scholars could always save time by cutting and pasting from their manuscript notes. When R. G. Collingwood complained of the methods of "scissors-and-paste" historians who compiled the testimonies of authorities instead of proceeding critically and inferentially, the term may have been more than a metaphorical designation. In Collingwood's academic context paste was a staple on sale at the stationer's, typically used for pasting passages cut out from one's notes (e.g. to prepare a lecture) but which could also apply to passages cut from printed pages. ${ }^{82}$ Indeed one Renaissance scholar has told me that he was advised as a graduate student to purchase a cheap edition of his main source in order to cut out quotations and paste them onto index cards from which to compose his dissertation. ${ }^{83}$

The perception of an overabundance of books led to more books being used in a great variety ways. Alongside the well-established methods of thorough reading and note-taking, which engaged the personal judgment and effort of the reader, early modern scholars also relied on shortcuts to "process" books so as to retrieve items of use with less investment of time and self. In some cases personal judgment was sacrificed when readers relied on the labor of others, notably professional compilers and amanuenses. In other cases the integrity of manuscripts and printed texts (notes, letters, and printed books) was sacrificed, when passages were cut and reused to save some of the labor of copying. At the same time idiosyncratic systems of abbreviation and note storage also heightened the private nature of reading. The proliferation of inventive methods of and aids to study, whether unique to individuals or spread more widely through official or unofficial teaching, can help us understand better not only the conditions of production of early modern scholarly and pedagogical works, but also the deep roots of the ways in which we, too, cope with what we now call information overload.

Harvard University.

\footnotetext{
${ }^{81}$ Note the exhibit on "Cut and paste around 1900. Newspaper clipping collections in the sciences" at the Max Planck Institut and the Medical History Museum in Berlin, organized by Anke te Heesen.

${ }^{82}$ See R. G. Collingwood, The Idea of History (Oxford, 1972), 257-61.

${ }^{83}$ Stephen Orgel, personal communication, referring to the advice of John Bullitt, of the English Department at Harvard.
} 